\title{
THE EFFECT OF MANGANESE ON THE GROWTH OF TOMATO CELLS IN SUSPENSION CULTURE
}

\author{
P.S.J.W. SERESINHE \\ Department of Crop Science, Faculty of Agriculture, University of Ruhuna, \\ Kamburupitiya.
}

(Received: 21 December 1995; accepted: 06 September 1996)

\begin{abstract}
The effects of $\mathrm{Mn}^{2+}$ concentration in the culture medium on the biomass production, nutrient content, cell division and viability were studied using tomato cells in suspension culture. The biomass and the dry weight were highest at Mn levels of 0.002 and $0.1 \mathrm{mM}$ when compared with cells grown with 0 or $0.2 \mathrm{mM} \mathrm{Mn}$ in the medium. Cells cultured on $0.2 \mathrm{mM} \mathrm{Mn}$ turned black by day 6 . Cells grown without added $\mathrm{Mn}(0 \mathrm{mM})$ turned brown by day 8 . The total number of cells as well as the number of viable cells were lowest, with Min levels of 0 and $0.2 \mathrm{mM}$. Manganese levels of 0.2 and $0 \mathrm{mM}$ in the medium led to toxicity and deficiency respectively. By day 8 all the macro-and micro-elements of cells grown either with 0.2 and $0 \mathrm{mM}$ Mn were low. This was probably due to the change in the cell mernbrane permeability which had led to the leaching of cell contents under the latter two $\mathrm{Mn}$ concentrations. There were no significant differences in the nutrient content of cells over a $\mathrm{Mn}$ range of 0.1 and $0.002 \mathrm{mM}$ in the medium. Therefore in spite of a concentration difference of 50 fold, tomato cells showed no deleterious effects to medium $\mathrm{Mn}$ within the latter concentration range.
\end{abstract}

Key Words: Cell culture, manganese, tomato.

\section{INTRODUCTION}

Manganese, an essential micro-nutrient for all higher plants, is absorbed as $\mathrm{Mn}^{2+}$. It is transiocated predominantly as the free divalent cation in xylem from the roots to the shoots. ${ }^{1}$ Unlike many other essential trace elements ${ }^{*}$ which are integral components of enzymes (e.g. $\mathrm{Cu}, \mathrm{Zn}, \mathrm{Fe}$ and Mo), Mn usually acts like an activator of enzymes and can be replaced by other metal ions. However the most important role of $\mathrm{Mn}$ in plants is its involvement in oxygen evolution in photosynthesis in higher plants. The protein that catalyses the water splitting reaction which is located in the thylakoid membrane, contains $4 \mathrm{Mn}$ atoms. ${ }^{2,3} \mathrm{Mn}$ is also a component of Mn super-oxide dismutase (Mn-SOD), which is present in the chloroplast, and protects the photosynthetic apparatus from the oxygen free radical - superoxide. Mn levels in the plant also affect the level of auxin in tissues by influencing the level of IAA oxidase ${ }^{4}$ and by being a cofactor involved in the synthesis of IAA. ${ }^{5}$ Though not well understood it seems that Mn is also important in root nodule formation in legumes. Mn differs from the other micro-nutrients in three important ways. Firstly, the insoluble higher oxide or oxide-Mn serves along with soil solution $\mathrm{Mn}^{2+}$, as a direct source of this element to plants. 
Secondly, the concentration of $\mathrm{Mn}^{2+}$ in the soil solution can vary by orders of magnitude within very short time spans. Finally, Mn may be accumulated by plants in amounts exceeding requirements by a factor of 50 or more. Generally plant needs are met at tissue levels of $20-40 \mathrm{mg} \mathrm{kg}^{-1}$ dry matter and toxic levels of $400-2000 \mathrm{mg} \mathrm{kg}^{-1}$ dry matter. ${ }^{6}$ Plants require a continuous supply of Mn since reuse within the plant is limited, especially at low level of supplies. ${ }^{7}$ Nutritionally adequate levels are supplied by nutritional solutions containing $0.002-0.005 \mathrm{mM}$ of the element. ${ }^{8,9}$ In contrast to these levels of Mn in solution cultures, Mn levels in tissue culture media vary from $0.045 \mathrm{mM}$ in $\mathrm{B}_{5}$ medium $^{10}$ to $0.1 \mathrm{mM}$ the highest in Murashige and Skoog medium ${ }^{11}$ (MS medium). Therefore the Mn concentration in $\mathrm{B}_{5}{ }^{10}$ and MS medium ${ }^{11}$ exceeds by factors of 22 and 50 respectively as compared with the nutritional solutions used for larger plants. ${ }^{8,9}$

Since there are few studies on the effects of $M n$ on suspension culture systems, a study was undertaken to test the effects of varying media Mn levels on the biomass production, cell division and their viability using tomato cells in suspension culture.

\section{METHODS AND MATERIALS}

Cells in suspension of tomato (Lycopersicon esculentum Mill cv. Rodeo) maintained in a $\mathrm{MS}^{11}$ medium $(\mathrm{pH}=5.8$, conductivity $=7 \mathrm{mmhos}$, and osmolality $=420$ $\mathrm{mOs} \mathrm{kg}$ ) were used in this study. Cultures maintained at a $\mathrm{Mn}$ concentration of $0.1 \mathrm{mM}$, were first sterile filtered using a membrane filter unit (Sartorius Membrane-filter, Germany) and rinsed four times with a MS medium without $\mathrm{Mn}$. The cells were resuspended in a medium without $\mathrm{Mn}$, and $20 \mathrm{ml}$ aliquots were transfered to $250 \mathrm{ml}$ Erlenmeyer flasks containing $150 \mathrm{ml}$ of $\mathrm{Mn}$ free culture medium and grown. In an initial test it was observed that cells treated as above could survive in a medium devoid of Mn for about 14 days and thereafter they lose their viability. After 10 days the cells were separated and resuspended in a MS medium without Mn. Twenty $\mathrm{ml}$ aliquots were then filter sterilized and the cells transfered to flasks containing treatment media with $(0.1,0.2,0.002$ $\mathrm{mM}$ ) and without ( $0 \mathrm{mM}$ ) Mn. Each treatment was replicated four times. The flasks were kept on a rotary shaker $(110 \mathrm{rpm})$ at $23^{\circ} \mathrm{C}$ and incubated under continuous fluorescent light $\left(100 \mu \mathrm{mol} \mathrm{m}^{-2} \mathrm{~s}^{-1}\right.$, PhilipsTL F40W/33). The biomass, dry weight and mineral element content of cells were determined as previously described, ${ }^{12}$ and briefly is as follows. A cell suspension was pipetted on to a membrane filter unit and the medium was drained away under pressure. The cells on the filter were then scraped carefully to pre-weighed plastic disks and the fresh weight determined. The disks with cells were then transferred to an oven and dried at $60^{\circ} \mathrm{C}$ for $24 \mathrm{~h}$. The cells were allowed to cool in a desiccator and their dry weights were determined. The dried cells were then ashed in a muffle furnace at $540^{\circ} \mathrm{C}$ for $24 \mathrm{~h}$ and the ash was dissolved in $2 \mathrm{~N} \mathrm{HCl}$ and this solution 
was used to determine the mineral elements. This was done by using a Inductively Coupled Plasma Photometer (Perkin Elmer). The nitrogen content of the dried cells was determined using a $\mathrm{N}$ analyser.

The number of viable cells was determined using a fluoroscein-di-acetate (FDA) solution (40 $\mathrm{mg}$ of FDA dissolved in $20 \mathrm{ml}$ acetone and $100 \mu \mathrm{l}$ from this solution was added to $1 \mathrm{ml}$ of $0.5 \mathrm{M}$ sucrose solution). The total number of cells was determined as described by Street. ${ }^{13}$ Prior separation of cells in cell aggregates was achieved by a control treatment with chromic acid $(6 \% \mathrm{w} / \mathrm{v}$ chromium-tri-oxide solution). ${ }^{14}$ The first count was taken immediately after the cells were transfered to treatment media. One $\mathrm{ml}$ cell suspension aliquots were first diluted 10 times with their respective media since dilution makes the counting much easier. One $\mathrm{ml}$ of the diluted suspension was pipetted out, and each of $0.1 \mathrm{ml}$ was used to determine both the total number of cells and the viable cells. The total number of cells was first determined microscopically under tungsten light $(\mathrm{x} 10)$. The number of viable cells under ultra violet light ( $\mathrm{x} 10)$ (where only the viable cells show a green fluorescence). Cells grown in media containing $0,0.1$ and $0.2 \mathrm{mM} \mathrm{Mn}$ were used to determine both the total cell number and viable cells. The latter parameters were determined at $0,4,8$ and 12 days. The statistical analysis was done using the Statgraphics Statistical Programme.

\section{RESULTS}

The effect of Mn on the biomass production is shown in Figure 1. The differences in biomasses under different treatments were first observed on day 4. Irrespective of the $\mathrm{Mn}^{2+}$ concentration in medium, there is a doubling in the biomass in all treatments in about three days. Cells growing in media either with 0.01 or $0.002 \mathrm{mM} \mathrm{Mn}$ showed a continuous growth. The biomass of cells in the presence of 0 and $0.2 \mathrm{mM} \mathrm{Mn}$ in medium showed a decreasing trend beginning from day 6 . Cells in the presence of $0.2 \mathrm{mM} \mathrm{Mn}$ showed a black discolouration by day 6 and those in the presence of $0 \mathrm{mM}$ Mn turned brown by day 8. Cells in latter two treatments were not viable by day 10 .

The dry weight of cells under varying Mn treatments is shown in Table 1. The dry weight of cells followed the same pattern as the biomass production. The macro-and micro-nutrient contents of cells are shown in Tables 2 and 3 respectively. There were no significant differences in nutrient content of cells at $\mathrm{Mn}$ levels of 0.1 and $0.002 \mathrm{mM}$ (Table 2). Cells growing with $0.2 \mathrm{mM} \mathrm{Mn}$ in medium had lower Mg contents when determined at day 2. Cells growing either with a high (0.2 $\mathrm{mM})$ or no $(0 \mathrm{mM}) \mathrm{Mn}$ in mediun had lower amounts of all macronutrients at day 8 , especially the reduction in Klevel is higher than for any other macro-nutrient. Cells growing in the presence of $0.2 \mathrm{mM} \mathrm{Mn}$ had lower $\mathrm{Zn}, \mathrm{Cu}$, 
and $\mathrm{Fe}$ whereas cells cultured without added $\mathrm{Mn}(0 \mathrm{mM})$ had higher levels of all these nutrients (Table 3). By day 8 cells growing either with 0.2 or $0 \mathrm{mM} \mathrm{Mn}$ in medium had lower contents of $\mathrm{Zn}, \mathrm{Cu}$, and $\mathrm{Fe}$ as compared with cells cultured with either 0.1 or $0.002 \mathrm{mM}$ added $\mathrm{Mn}$. The total number of cells in all treatments did not vary to a large extent until day 4 (Fig. 2). Thereafter no significant increase in the cell number was observed in treatments receiving either 0 or $0.2 \mathrm{mM} \mathrm{Mn}$. Whereas a continuous increase in the cell number was observed for cells growing with a $\mathrm{Mn}$ level of $0.1 \mathrm{mM}$. At concentrations of 0 and $0.2 \mathrm{mM} \mathrm{Mn}$, the number of non viable cells increased dramatically after day 4 (Fig. 3), while plasmolysis of cells was not observed at the higher $\mathrm{Mn}$ level of $0.2 \mathrm{mM}$.

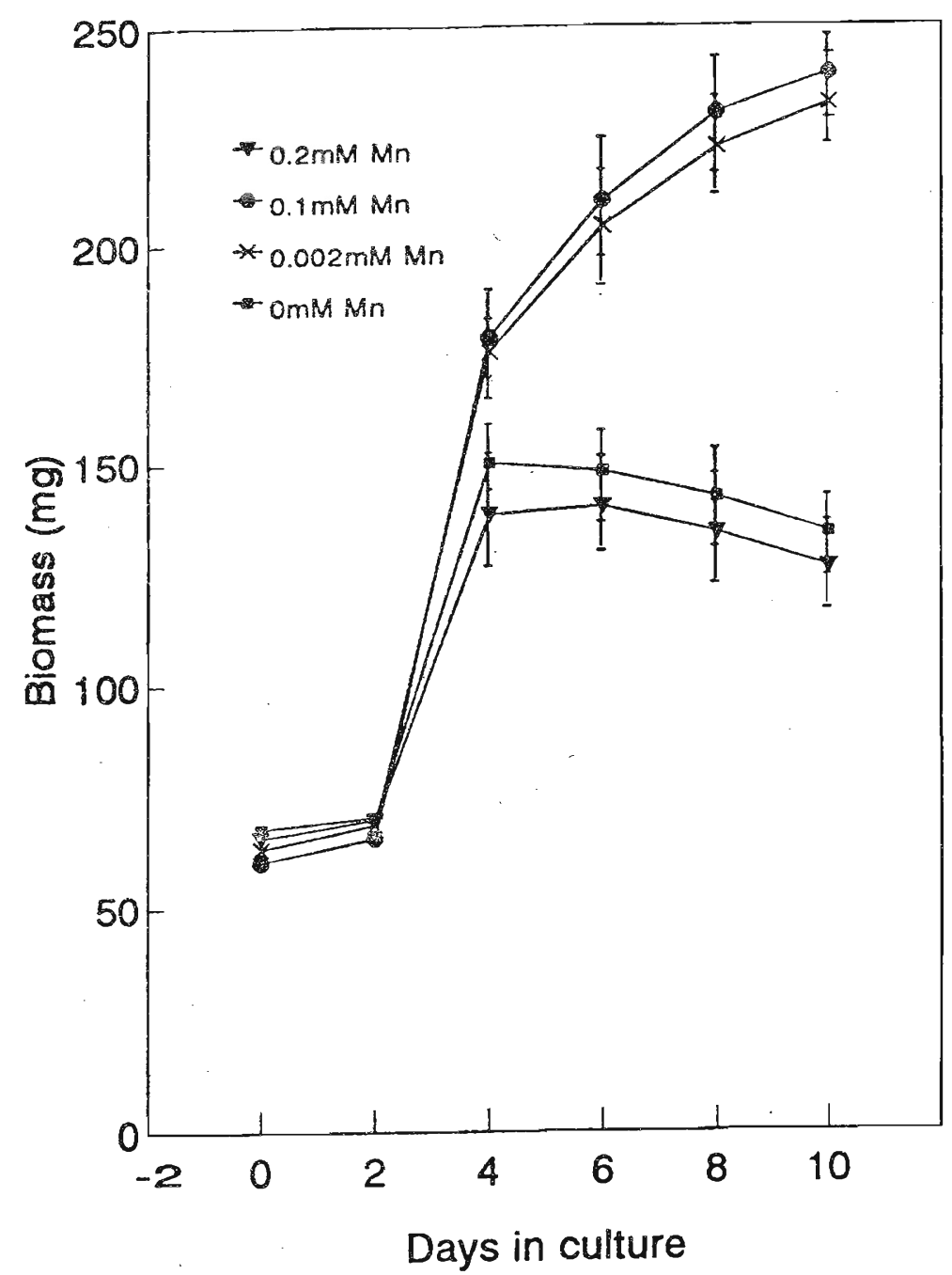

Figure 1: The effect of four Mn levels in medium on the biomass production of tomato cells in suspension culture. (Vertical bars indicate the standard error). 
Table 1: The effect of varying manganese levels in media on the dry weight (mg) of tomato cells in suspension culture.

Days in culture

\begin{tabular}{lllllll}
\hline $\operatorname{Mn}(\mathrm{mM})$ & 0 & 2 & 4 & 6 & 8 & 10 \\
\hline
\end{tabular}

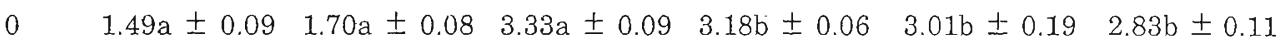

$0.002 \quad 1.45 a \pm 0.05 \quad 1.61 \mathrm{a} \pm 0.11 \quad 3.69 \mathrm{a} \pm 0.06 \quad 4.23 \mathrm{a} \pm 0.05 \quad 4.45 \mathrm{a} \pm 0.11 \quad 4.60 \mathrm{a} \pm 0.12$

$0.1 \quad 1.39 \mathrm{a} \pm 0.21 \quad 1.63 \mathrm{a} \pm 0.22 \quad 3.72 \mathrm{a} \pm 0.04 \quad 4.32 \mathrm{a} \pm 0.03 \quad 4.51 \mathrm{a} \pm 0.12 \quad 4.54 \mathrm{a} \pm 0.09$

$0.2 \quad 1.46 \mathrm{a} \pm 0.22 \quad 1.69 \mathrm{a} \pm 0.31 \quad 3.39 \mathrm{a} \pm 0.06 \quad 3.36 \mathrm{~b} \pm 0.02 \quad 3.06 \mathrm{~b} \pm 0.19 \quad 2.85 \mathrm{~b} \pm 0.26$

Values followed by the same letter within a column are not significant at $\mathrm{p}=0.05$ as determined by the Duncans multiple range test. Each value is the average of four replicates (average \pm standard error).

Table 2: The effect of varying Mn levels in media on the macro nutrient content $(\%)$ of cells.

\begin{tabular}{lccccc}
\hline \multicolumn{7}{c}{ DAY 0 } \\
\hline $\mathrm{Mn}(\mathrm{mM})$ & $\mathrm{N}$ & $\mathrm{P}$ & $\mathrm{K}$ & $\mathrm{Ca}$ & $\mathrm{Mg}$ \\
\hline 0 & $3.03 \mathrm{a} \pm 0.25$ & $0.88 \mathrm{a} \pm 0.10$ & $6.01 \mathrm{a} \pm 0.75$ & $1.06 \mathrm{a} \pm 0.12$ & $0.60 \mathrm{a} \pm 0.09$ \\
0.002 & $3.33 \mathrm{a} \pm 0.15$ & $0.91 \mathrm{a} \pm 0.08$ & $5.93 \mathrm{a} \pm 0.90$ & $0.94 \mathrm{a} \pm 0.16$ & $0.50 \mathrm{a} \pm 0.10$ \\
0.1 & $3.20 \mathrm{a} \pm 0.19$ & $0.96 \mathrm{a} \pm 0.11$ & $5.91 \mathrm{a} \pm 0.65$ & $1.01 \mathrm{a} \pm 0.20$ & $0.58 \mathrm{a} \pm 0.14$ \\
0.2 & $3.37 \mathrm{a} \pm 0.36$ & $0.90 \mathrm{a} \pm 0.18$ & $6.00 \mathrm{a} \pm 0.43$ & $1.05 \mathrm{a} \pm 0.19$ & $0.59 \mathrm{a} \pm 0.11$ \\
\hline \hline \multicolumn{7}{c}{} & \multicolumn{5}{c}{$\mathrm{DAY} 4$} & & \\
\hline $\mathrm{Mn}(\mathrm{mM})$ & $\mathrm{N}$ & $\mathrm{P}$ & $\mathrm{K}$ & $\mathrm{Ca}$ & $\mathrm{Mg}$ \\
\hline 0 & $3.19 \mathrm{a} \pm 0.11$ & $1.00 \mathrm{a} \pm 0.14$ & $5.86 \mathrm{a} \pm 0.45$ & $1.00 \mathrm{a} \pm 0.16$ & $0.67 \mathrm{a} \pm 0.07$ \\
0.002 & $3.43 \mathrm{a} \pm 0.05$ & $0.96 \mathrm{a} \pm 0.21$ & $5.96 \mathrm{a} \pm 0.38$ & $1.01 \mathrm{a} \pm 0.14$ & $0.64 \mathrm{a} \pm 0.09$ \\
0.1 & $3.23 \mathrm{a} \pm 0.14$ & $1.02 \mathrm{a} \pm 0.03$ & $6.02 \mathrm{a} \pm 0.36$ & $0.94 \mathrm{a} \pm 0.21$ & $0.63 \mathrm{a} \pm 0.08$ \\
0.2 & $2.99 \mathrm{a} \pm 0.12$ & $0.95 \mathrm{a} \pm 0.20$ & $5.88 \mathrm{a} \pm 0.28$ & $0.98 \mathrm{a} \pm 0.09$ & $0.37 \mathrm{~b} \pm 0.10$ \\
\hline \hline \multicolumn{7}{c}{} & & & $\mathrm{DAY} 8$ & & \\
\hline $\mathrm{Mn}(\mathrm{mM})$ & $\mathrm{N}$ & $\mathrm{P}$ & $\mathrm{K}$ & $\mathrm{Ca}$ & $\mathrm{Mg}$ \\
\hline 0 & $1.99 \mathrm{~b} \pm 0.12$ & $0.59 \mathrm{~b} \pm 0.09$ & $2.00 \mathrm{~b} \pm 0.39$ & $0.26 \mathrm{~b} \pm 0.22$ & $0.19 \mathrm{~b} \pm 0.03$ \\
0.002 & $3.20 \mathrm{a} \pm 0.10$ & $0.95 \mathrm{a} \pm 0.10$ & $6.12 \mathrm{a} \pm 0.89$ & $0.92 \mathrm{a} \pm 0.17$ & $0.58 \mathrm{a} \pm 0.11$ \\
0.1 & $3.12 \mathrm{a} \pm 0.19$ & $0.91 \mathrm{a} \pm 0.11$ & $6.05 \mathrm{a} \pm 0.78$ & $0.96 \mathrm{a} \pm 0.20$ & $0.54 \mathrm{a} \pm 0.15$ \\
0.2 & $1.96 \mathrm{~b} \pm 0.20$ & $0.67 \mathrm{~b} \pm 0.06$ & $1.97 \mathrm{~b} \pm 0.65$ & $0.30 \mathrm{~b} \pm 0.13$ & $0.24 \mathrm{~b} \pm 0.09$ \\
\hline
\end{tabular}

Values within a column followed by the same letter are not significant at $\mathrm{p}=0.05$ as determined by the Duncans multiple range test. Each value is the average of four replicates (average \pm standard error). 
Table 3: The effect of varying Mn levels in media on the micro-nutrient content ( $\mu \mathrm{g} \mathrm{g}^{-1}$ dry weight) of cells.

DAY 0

\begin{tabular}{lllll}
\hline $\mathrm{Mn}(\mathrm{mM})$ & $\mathrm{Mn}$ & $\mathrm{Cu}$ & $\mathrm{Fe}$ \\
\hline
\end{tabular}

$\begin{array}{lllll}0 & 11.60 \mathrm{a} \pm 1.23 & 64.18 \mathrm{a} \pm 8.97 & 30.06 \mathrm{a} \pm 3.65 & 140.49 \mathrm{a} \pm 10.25 \\ 0.002 & 11.43 \mathrm{a} \pm 0.92 & 64.10 \mathrm{a} \pm 5.39 & 30.94 \mathrm{a} \pm 4.55 & 140.55 \mathrm{a} \pm 11.02 \\ 0.1 & 11.49 \mathrm{a} \pm 1.69 & 64.48 \mathrm{a} \pm 9.75 & 30.09 \mathrm{a} \pm 5.03 & 139.87 \mathrm{a} \pm 9.90 \\ 0.2 & 11.28 \mathrm{a} \pm 1.59 & 63.85 \mathrm{a} \pm 6.23 & 30.34 \mathrm{a} \pm 6.48 & 140.22 \mathrm{a} \pm 10.23\end{array}$

DAY 4

\begin{tabular}{lllll}
\hline $\mathrm{Mn}(\mathrm{mM})$ & $\mathrm{Mn}$ & $\mathrm{Cu}$ & $\mathrm{Fe}$ \\
\hline
\end{tabular}

$\begin{array}{lrllll}0 & 9.68 \mathrm{c} \pm 0.98 & 66.53 \mathrm{c} \pm 9.52 & 32.99 \mathrm{~b} \pm 3.25 & 150.99 \mathrm{c} \pm 14.23 \\ 0.002 & 79.43 \mathrm{a} \pm 10.25 & 56.40 \mathrm{a} \pm 4.23 & 26.90 \mathrm{a} \pm 4.21 & 138.55 \mathrm{a} \pm 10.33 \\ 0.1 & 81.11 \mathrm{a} \pm 11.02 & 57.45 \mathrm{a} \pm 3.25 & 27.72 \mathrm{a} \pm 2.23 & 139.87 \mathrm{a} \pm 10.25 \\ 0.2 & 120.38 \mathrm{~b} \pm 25.30 & 51.72 \mathrm{~b} \pm 2.25 & 22.43 \mathrm{a} \pm 3.44 & 126.22 \mathrm{~b} \pm 0.97\end{array}$

DAY 8

\begin{tabular}{lrcrrr}
\hline Mn $(\mathrm{mM})$ & $\mathrm{Mn}$ & $\mathrm{Zn}$ & $\mathrm{Cu}$ & $\mathrm{Fe}$ \\
\hline 0 & $6.29 \mathrm{c} \pm 0.03$ & $49.02 \mathrm{a} \pm 5.22$ & $17.43 \mathrm{~b} \pm 0.05$ & $95.23 \mathrm{~b} \pm 13.93$ \\
0.002 & $79.86 \mathrm{a} \pm 11.22$ & $55.63 \mathrm{a} \pm 4.34$ & $25.91 \mathrm{a} \pm 1.23$ & $119.83 \mathrm{a} \pm 18.36$ \\
0.1 & $81.51 \mathrm{a} \pm 10.22$ & $54.67 \mathrm{a} \pm 5.21$ & $25.22 \mathrm{a} \pm 2.25$ & $117.61 \mathrm{a} \pm 14.22$ \\
0.2 & $90.24 \mathrm{~b} \pm 13.20$ & $49.21 \mathrm{~b} \pm 3.22$ & $19.73 \mathrm{~b} \pm 1.98$ & $96.20 \mathrm{~b} \pm 12.57$ \\
\hline
\end{tabular}

Values followed by the same letter within a column are not significant at $p=0.05$ as determined by the Duncans multiple range test. Each value is the average of four replicates (average \pm standard error). 


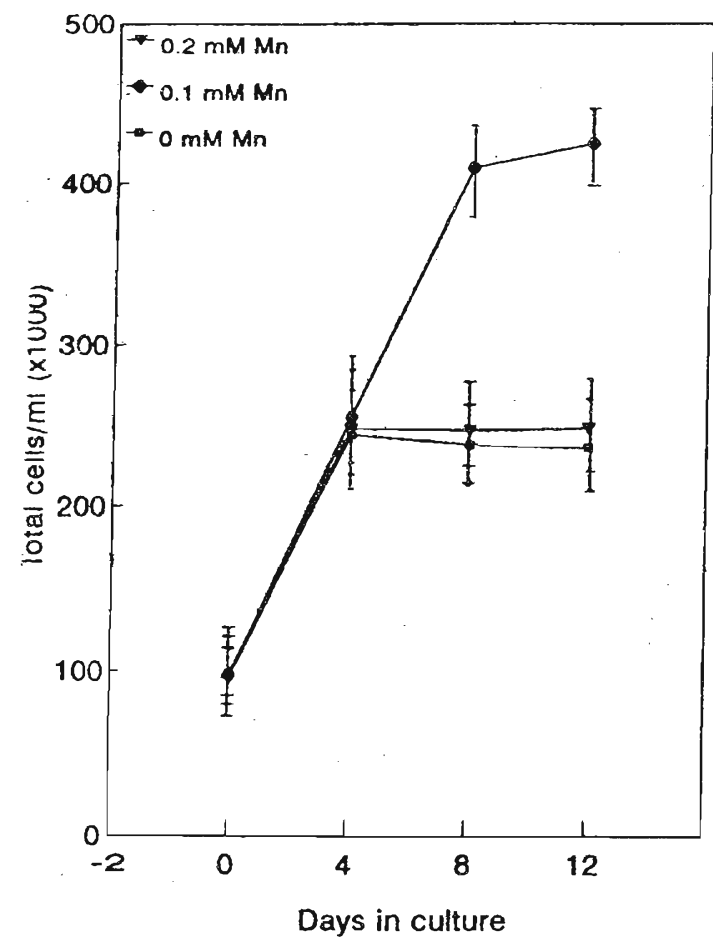

Figure 2: The effect of three $\mathrm{Mn}$ levels in the medium on the total number of cells. (Vertical bars indicate the standard error).

\section{DISCUSSION}

There could be two explanations for the ability of cells to grow with no added Mn $(0 \mathrm{mM} \mathrm{Mn})$ in the medium until day 4. Firstly, though the cells were grown in a medium without $\mathrm{Mn}$ and starved for some time, the cells have some $\mathrm{Mn}$ at the onset of the experiment and the "carry over" may have sufficed to sustain the growth of cells for a few days. Secondly, though not in large amounts, some of the salts used for the formulation of the medium contained $\mathrm{Mn}$ as an impurity (e.g. both $\mathrm{FeSO}_{4} .7 \mathrm{H}_{2} \mathrm{O}$ and $\mathrm{ZnSO}_{4}$ contains about $0.05 \% \mathrm{Mn}$ ); since micronutrients are needed in minute quantities, even very low levels, well below an optimum would nevertheless enable the cells to maintain their activities for some days. Since $\mathrm{Mn}$ is an essential element for all higher plants, the growth of cells when there was no added $\mathrm{Mn}$ in the medium was limited after day 4 . This indicates that the rate of cell division was impaired when there was no added $\mathrm{Mn}$ in the medium (Fig. 2). The brown colour observed by day 8 indicate that the cells were dying due to lack of $\mathrm{Mn}$ in the medium or due to the production of secondary metabolites under Mn deficiency. Cells growing in a medium deficient in Mn loose their viability and almost one third of the cells were non-viable by day 12 (Fig. 3). 


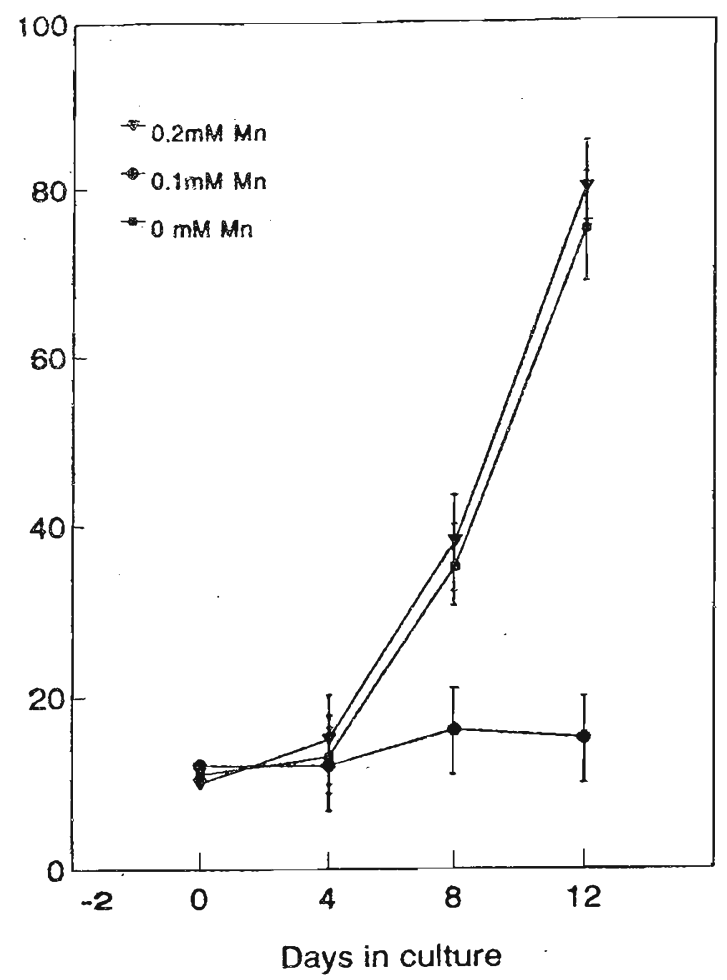

Figure 3: The effect of three Mn levels on the non-viable cell number. (Vertical bars indicate the standard error).

Cells growing in the presence of $0.2 \mathrm{mM} \mathrm{Mn}$ in the medium showed a black discoloration by day 8 probably indicating that the cells were suffering from toxicity. This is indicated by the high $\mathrm{Mn}$ ion content of the cells at day 4 (Table 3); further the $\mathrm{Mn}$ content of cells receiving $0.2 \mathrm{mM} \mathrm{Mn}$ was about $120 \mu \mathrm{g} \mathrm{g}^{1} \mathrm{dry}$ weight (DW) against about $80 \mu \mathrm{g} \mathrm{g}^{-1} \mathrm{DW}$ for 0.1 and $0.002 \mathrm{Mn}$ levels. It appears that high $\mathrm{Mn}$ levels in the medium arrest both cell division and cell viability (Figs. 3 and 4). The common Mn toxicity symptoms observed with whole plants growing in a field or in culture solution include crinkling of the leaf in conjunction with chlorosis and black or brown spots; symptoms are often more severe on the older leaves. Appearance of black spots on leaves at a later stage is attributed to a greatly increased polyphenol oxidase activity and associated malfunction in phenolic and lignin metabolism, ${ }^{15}$ or the deposition of oxides of $\mathrm{Mn} .{ }^{16}$ Whether the above observations are also applicable to the blackening of tomato cells at higher Mn concentrations is yet to be elucidated. Nable \& Loneragan $(1984,)^{7}$ using a split-root system showed that growth of roots without an external Mn supply was $50 \%$ less as compared to roots of the same plant receiving an adequate supply of Mn from the external solution. In Mn deficient plants the formation of lateral roots ceased completely. ${ }^{17}$ Reduction in the root growth in above studies 
is very likely due to reduced meristamatic activity. The Mn status of plants has profound effects on the auxin balance of tissues and an imbalance in Mn nutrition could impair both cell division and elongation. ${ }^{18}$ There is ample evidence to show that Mn might be a cofactor for the indole acetic acid system, and that both deficient and toxic Mn levels in leaves leads to exceptionally high IAA oxidase activity which might lead to enhanced auxin degradation in tissues. In the present study it is not clear whether the reduced rate of cell division in treatments receiving 0.2 and $0 \mathrm{mM} \mathrm{Mn}$ was due to an imbalance in auxins.

Despite a fifty fold concentration difference there are no significant differences both in the biomass produced and dry weights of cells receiving either 0.1 or $0.002 \mathrm{mM} \mathrm{Mn}$. This suggests that the tomato cells in suspension culture are relatively tolerant to $\mathrm{Mn}$. The low levels of macro nutrients determined by day 8 (Table 2 ) in cells receiving 0.2 and $0 \mathrm{mM}$ Mn is explained by the fact that toxicity $(0.2 \mathrm{mM})$ as well as deficiency $(0 \mathrm{mM})$ lead to the death of cells. In such cells the membrane integrity is impaired. This leads to leaching of cell contents especially potassium, the most abundant cation in the cells. That excess Mn in the medium $(0.2 \mathrm{mM})$ depress the uptake of $\mathrm{Mg}$ (Table 2) has also been observed by other workers. Work done with soybeans, ${ }^{19}$ tomatoes $^{20}$ and beans ${ }^{16}$ show that toxic levels of Mn levels in the growing medium decrease both the $\mathrm{Mg}$ and Ca content of plants. Heenan \& Campbell (1981) ${ }^{19}$ assume that apart from depression in $\mathrm{Mg}$ uptake, excess $\mathrm{Mn}$ in the growth medium in some way blocks the binding sites for $\mathrm{Mg}$. In contrast to $\mathrm{Mg}$, the $\mathrm{K}$ content of cells did not vary much within treatments until day 4. Previous work shows that toxic levels of $\mathrm{Mn}$ in the medium do not have direct effects on K levels. ${ }^{19}$ By day 4 cells cultured with no $\mathrm{Mn}$ in the medium had higher levels of $\mathrm{Zn}, \mathrm{Cu}$ and $\mathrm{Fe}$ than cells supplied with either sufficient ( 0.1 and $0.002 \mathrm{mM} \mathrm{Mn}$ ) or toxic levels $(0.2 \mathrm{mM} \mathrm{Mn})$, indicating that absorption of these elements is enhanced by lack of $\mathrm{Mn}$ in the medium. In contrast, higher levels of $\mathrm{Mn}$ in the medium depressed the uptake of $\mathrm{Fe}$ by cells. Such interactions between $\mathrm{Mn}$ and $\mathrm{Fe}$ have been observed by many workers. ${ }^{21,22}$

The critical deficiency levels of $\mathrm{Mn}$ are in the range of $10-20 \mathrm{mg} \mathrm{g}^{-1} \mathrm{DW}$ in mature leaves ${ }^{23}$ and surprisingly this range is consistent regardless of the plant species or cultivar or the prevailing environmental conditions. In the present experiment cells receiving no $\mathrm{Mn}$ contained almost $10 \mathrm{mg} \mathrm{g}^{-1}$. DW determined at day 4 but cellular Mn by day 8 was lower than the values obtained by Ohki et al. (1970). ${ }^{23}$ This was due to the loss of cell contents caused by leaching. In contrast to this narrow range of critical deficiency levels in leaves, the critical toxicity levels vary widely among plant species and environmental conditions. Even within species the critical toxicity levels can vary by a factor of about 3 to 5 among cultivars. ${ }^{24}$ Using a large number of plant species it has been shown that at a level causing critical toxicity (defined as $10 \%$ reduction in dry weight), the shoots of maize and sunflower contained 200 and $5300 \mathrm{mg} \mathrm{Mn} \mathrm{g}^{-1} \mathrm{DW}$ respectively. ${ }^{24}$ Tomato plants grown with $50 \mu \mathrm{M} \mathrm{Mn}$ in the medium contained very high $\mathrm{Mn}$ 
concentrationsof $916 \mu \mathrm{gg}^{-1} \mathrm{DW}$ and $2085 \mu \mathrm{g} \mathrm{g}^{-1} \mathrm{DW}$ in shoots and in older leaves respectively: ${ }^{20}$ Even at these higher $\mathrm{Mn}$ levels they could not observe any $\mathrm{Mn}$ toxicity symptoms. The values for growing leaves are thus very much higher than the values obtained with tomato cells in suspension culture with $0.2 \mathrm{mM}$ added Mn (day 4)(Table 3). It appears thus, that tomato cells in suspension culture growing in the presence of $0.2 \mathrm{mM} \mathrm{Mn}$ in culture medium show far greater sensivity to critical concentrations of $\mathrm{Mn}$ than whole plants.

\section{References}

1. Graham R.D. (1979). Transport of $\mathrm{Cu}$ and $\mathrm{Mn}$ to the xylem exudate of sunflower. Plant Cell Environment 2: 139-143.

2. Prince R.C. (1986). Manganese at the active site of the chloroplast oxygen evolving complex. Trends in Biochemical Sciences 132: 491-496.

3. Babcock G.T. (1987). The photosynthetic oxygen-evolving process. New Compendium in Biochemistry 15: 125-158.

4. Morgan P.W., Taylor D.M. \& Joham H.E. (1976). Manipulation of IAAoxidase activity and oxygen deficiency symptoms in intact cotton plants with Mn nutrition. Physiologia Plantarum 37: 149-156.

5. Gross G.G. (1980). The biochemistry of lignification. Advances in Botanical Research 8: 26-63.

6. Foy C.D., Chaney R.L. \& White M.C. (1978). The physiology of metal toxicity in plants. Annual Reviews of Plant Physiology 29: 511-566.

7. Nable R.O. \& Loneragen J.F. (1984). Translocation of Manganese in subterranean clover (Trifolium subterranean L. cv. Seaton Park). Australian Journal of Plant Physiology 11: 1-18.

8. Hoagland D.R. \& Arnon D.J. (1950). The water-culture method of growing plants without soil. Californian Agricultural Experimental Station Circulars. 347.

9. Reisenauer H.M. (1969). A technique for growing plants in controlled levels of nutrients. Soil Science 108: 350-353.

10. Gamborg O.L., Miller R.A. \& Ojima K. (1968). Nutrient requirements of suspension cultures of soybean root cells. Experimental Cell Research 50: 151-158. 
11. Murashige T. \& Skoog F. (1962). A revised medium for rapid growth and bioassays of tobacco tissue cultures. Physiologia Plantarum 15: 473-497.

12. Seresinhe P.S.J.W. \& Oertli J.J. (1991). Effects of boron on tomato cell suspensions. Physiologia Plantarum 81: 31-36.

13. Street H.E. (1973). Cell (suspension) culture-techniques. In: Plant tissue and cell culture, Botanical monographs. (Ed. H.E. Street) 11: pp . 31-35. Blackwell Scientific Publications, Oxford.

14. Butcher D.W. \& Street H.E. (1960). The effects of gibberelines on the growth of excised tomato roots. Journal of Experimental Botany 11: 206-216.

15. Higuchi T. (1981). Extracellular carbohydrates. In: Encyclopaedia of plant physiology. (Ed. A. Pirson \& M.H. Zimmerman) 13: pp. 194-224. Springer Verlag, New York.

16. Horst W.J. \& Marschner H. (1977). Effect of excessive manganese supply on uptake and translocation of calcium in bean plants (Phaseolus vulgaris L.). Zeitschrift fuer Pflanzenphysiologie 87: 137-148.

17. Abbot A.J. (1967). Physiological effects of micro-nutrient deficiencies in isolated roots of Lycopersicon esculentum. New Phytology 66: 419-437.

18. Neuman K.H. \& Steward F.C. (1968). Investigations on the growth and metabolism of cultured explants of Daucus carota. 1. Effects of iron, molybdenum and manganese on growth. Planta 81: 333-350.

19. Heenan D.P. \& Campbell L.C. (1981). Influence of potassium and manganese on growth and uptake of magnesium by soybeans (Glycine max L. Merr cv. Bragg). Plant and Soil 61: 447-456.

20. Le Bot J., Kirkby E.A. \& Van Beusichem M.L. (1990). Manganese toxicity in tomato plants. Effects on cation uptake and distribution. Journal of Plant Nutrition 13(5): 513-525.

21. Brown J.C. \& Jones W.E. (1977). Manganese and iron toxicities dependant on soybean varieties. Communications in Soil Science and Plant Analysis 8: 1-15.

22. Heenan D.P. \& Campbell L.C. (1983). Manganese and iron interactions on their uptake and distribution in soybean (Glycine max L. Merr.). Plant and Soil 70: 317-326. 
23. Ohki K., Wilson D.O. \& Anderson O.E. (1981). Manganese deficiency and toxic sensivities of soybean cultivars. Agronomy Journal 72: 713-716.

24. Edwards D.J. \& Asher C.J. (1982). Tolerance of crop and pasture species to manganese toxicity. (Ed. A. Scaife). In: Proceedings of the Ninth International Plant Nutrition Colloquium Vol. 1. Commonwealth Agricultural Bureau, Wallingford, Oxon. 